\title{
MULTIPLE MYELOMA. III. EFFECT OF URETHANE THERAPY ON PLASMA CELL GROWTH, ABNORMAL SERUM PROTEIN COMPONENTS AND BENCE JONES PROTEINURIA ${ }^{1}$
}

\author{
By R. WAYNE RUNDLES, M. L. DILLON,² AND EDITH S. DILLON ${ }^{3}$ \\ (From the Department of Medicine, Duke University School of Medicine and the Hematology \\ Laboratory, Duke Hospital, Durham, North Carolina.)
}

(Submitted for publication March 20, 1950; accepted, June 5, 1950)

Multiple myeloma is a unique malignant disease, usually classified as a form of sub-leukemia, that results from the proliferation of abnormal plasma cells within the bone marrow. The cause of the cellular proliferation is unknown. The clinical features of multiple myeloma are varied and relate to replacement or alteration of the hemopoietic tissues, demineralization of the skeleton about areas of plasma cell growth, abnormal protein metabolism, and impairment of renal function $(1,2)$.

The abnormal protein metabolism in multiple myeloma has long been of especial interest. The first knowledge of the disease indeed dates from $\mathrm{H}$. Bence Jones' classic study somewhat over 100 years ago of a peculiar urinary protein excreted by a grocer who died with "mollities ossium" (3). The occurrence of this protein in different diseases and its chemical properties became the subject of a multitude of studies in later years (4-10). It is precipitated by strong mineral acids and by sulfosalicylic acid. When heated in a concentration of less than $0.40 \%$, at $\mathrm{pH}$ of 4.6 to 5.2 in the presence of salt, it coagulates at the low temperature of $45-56^{\circ} \mathrm{C}$. and becomes quantitatively insoluble at $70^{\circ} \mathrm{C} .(7,8)$. At $100^{\circ} \mathrm{C}$. it dissolves, if the acidity is sufficiently great, and precipitates again when it is cooled. Occasionally the native protein precipitates from the urine in the cold (11). It has been crystalized on several occasions $(9,12)$.

An increased amount of protein in the serum in multiple myeloma was first recognized by Ellinger in 1899 (13). He studied a patient who had protein in both the blood and ascitic fluid that gave

1 This research has been supported by grants from the American Cancer Society upon recommendation of the Committee on Growth of the National Research Council, and from the U. S. Public Health Service.

We are greatly indebted to Dr. J. W. Beard for use of electrophoretic facilities.

2 Assistant Resident in Surgery, Duke Hospital.

${ }^{3}$ Research Assistant, Department of Surgery. typical Bence Jones precipitation reactions. In 1919 Jacobson reported a very thorough study of a patient who excreted 0.7-0.8 grams of Bence Jones protein per $100 \mathrm{cc}$. of urine (14). A heavy, creamy precipitate was produced by heating the serum to $56^{\circ} \mathrm{C}$. When this precipitate was separated from the serum and purified by washing several times with distilled water, a protein exhibiting typical Bence Jones properties could be demonstrated. A large quantity of this abnormal protein, 7.86 grams per $100 \mathrm{cc}$., was present in the blood serum obtained from the heart at autopsy. In 1928 Perlzweig, Delrue and Geschickter (15) emphasized multiple myeloma as one of the relatively few diseases in which hyperproteinemia may occur (16).

The numerous important studies $(7,11,15$, 17-29) during recent years of the serum and urinary proteins of multiple myeloma utilizing neutral salt precipitation, electrophoresis, ultracentrifugation, and immunochemical methods have been admirably reviewed by Gutman (30). Bence Jones protein is mainly characterized by its almost exclusive occurrence in malignancies involving the hemopoietic or lymphoid tissues (6) and by its peculiar coagulation reactions when heated. The molecular weight has been calculated from ultracentrifuge and diffusion experiments at slightly less than 37,000. On fractional precipitation with neutral salts, it has the solubility characteristics of globulin, but rather wide variations in precipitation range occur in specimens obtained from different individuals. Electrophoretic studies in many instances have shown remarkably homogenous proteins but the mobility of specimens obtained from different individuals ranges from gamma to that of beta globulin. When studied immunologically, specific precipitins of at least two antigenic types have been found $(12,27,31)$. The amino acid composition has been reinvestigated 
recently by improved methods (32-34). Like gamma globulin, Bence Jones protein has a high hydroxyamino acid content, but an anomalous finding was the absence of the essential amino acid methionine (33).

The hyperproteinemia of multiple myeloma, often a distinctive feature especially in patients without heavy proteinuria, has been found to result from the presence in the serum of abnormal protein components partly compensated for by a reduction in the albumin (30). A compilation of a large number of cases reported before 1941 showed total serum protein values in excess of 8.0 grams per $100 \mathrm{cc}$. in over $60 \%$ (21). Protein fractionation by the Howe method using sodium sulfate usually showed a reduction in the albumin and an increase in the globulin concentration. The globulin increments in different patients were, like the urinary proteins, strikingly heterogeneous in their solubility in salt solutions. Electrophoretic studies, particularly helpful in the investigation of sera of patients with multiple myeloma, have confirmed this heterogeneity in serum protein pattern. Many sera contain large peaks of electrophoretically homogenous protein with mobilities that range in different instances from slower than the mobility of gamma to that of beta globulin. These are usually associated with decreased albumin and in some instances with moderate increases in the alpha globulins $(17,19,21$, $24,27,35,36)$. Patterns with large peaks in the beta region or intermediate between beta and gamma are virtually diagnostic of myeloma (27). In some sera only minor abnormalities of pattern in the region of the gamma or beta globulins can be detected (17). Virtually normal electrophoretic patterns may be found with the serum from patients who excrete large amounts of Bence Jones protein in the urine. A number of patients with multiple myeloma having cold precipitable "cryoglobulins" in the plasma have been reported (11, $20,22,37-45$ ).

It has long been assumed that the abnormal proteins in multiple myeloma were produced by the proliferating plasma cells, transported in the blood stream, and finally excreted in part at least in the urine. The most direct evidence as to the origin of the proteins was recently obtained by Martin (46). He extracted myeloma tumor tissue obtained at necropsy with saline and obtained pro- tein with ultracentrifugal and electrophoretic properties similar to those of abnormal components present in the plasma. Ågren found that the protein obtained from a myelomatous tumor had an amino acid composition similar to that of Bence Jones protein obtained from the urine (32).

The relation of the abnormal serum components to Bence Jones urinary protein remains in many respects unsettled (30). When different specimens of Bence Jones protein are added to normal sera some but not all of the abnormal Howe and electrophoretic patterns can be reproduced (21). The electrophoretic mobilities of the abnormal serum components have generally been somewhat less than that of the urinary protein from the same individual. Large serum protein increments, especially those with the mobility of beta globulin or intermediate between beta and gamma have been shown in some instances to be due to Bence Jones proteinemia $(21,27)$. In other instances, especially where peaks with gamma mobility occur, the protein in the serum has been of much larger molecular size, differing in solubility and even in antigenic property (27). It has been suggested that the gamma complexes may represent antibodies to Bence Jones protein (30).

With the finding that urethane (ethyl carbamate) given in doses of 90-300 grams over a period of six to ten weeks to patients with multiple myeloma may produce striking reductions in the number of abnormal plasma cells in the bone marrow and morphologic changes indicative of arrested or retarded growth, it was apparent that a new means of studying the cellular and protein abnormalities in this disease was available (2). Dillon and colleagues reported the reduction or virtual disappearance of abnormal serum components in the electrophoretic patterns of three patients following urethane therapy (47). An extension of those studies is herein reported, correlating the serum protein changes with clinical, hematologic and other data in 11 patients who have been treated and followed from three to 28 months, some through repeated relapses and remissions. Information bearing on the relation of plasma cell proliferation to the major and minor abnormalities in serum protein pattern and to Bence Jones urinary protein, and the significance of serum protein complexes ordinarily not due to Bence Jones proteinemia has been obtained. An important 
clue to the biochemical mechanism of urethane action may be provided by the evidence that the abnormal plasma cells may become dependent on the chemical after its prolonged use.

\section{MATERIALS AND METHODS}

Blood samples were permitted to clot at room temperature for a few hours for separation of the serum. The sera were freed of red blood cells by centrifugation and frozen awaiting analysis or filtered through a Seitz filter into sterile rubber stoppered tubes and stored at $4^{\circ} \mathrm{C}$. to observe formation of cryoglobulins before freezing. Samples for electrophoresis were prepared by diluting $5 \mathrm{cc}$. of serum to $15 \mathrm{cc}$. with barbital buffer of $\mathrm{pH}$ 8.6 and 0.1 ionic strength and dialysed at $5-8^{\circ} \mathrm{C}$. for 36 hours or more in a constant flowing rocking dialysis chamber against at least 3 liters of buffer. The preparations were filtered at $5-8^{\circ} \mathrm{C}$. through a Seitz filter to clear if necessary (48).

Electrophoresis was carried out at $1^{\circ} \mathrm{C}$. in a doublelength rectangular glass cell that allows a maximum observable migration of about $9 \mathrm{~cm}$. The boundaries were allowed to migrate for about three hours in an electrical field of approximately 7 volts per $\mathrm{cm}$. The patterns representing the migrating boundaries were recorded by the method of crossed slits described by Svensson.

Component analyses were made by measurement from photographic enlargements of the electrophoretic diagrams in which the components were separated by vertical lines to the base at the minima between the peaks. The base line was removed from the starting boundary by lowering the third blade of the angle slit and was reconstructed in the enlargement by drawing lines connecting the portions of the base line remaining at the extremities of the patterns. The respective areas are bounded by the midline of the curve above, and the midline of the base below. The mobilities of the various components were calculated from the distances measured from the starting point of migration to the maximum ordinates of the respective peaks. Calculations were made for both the ascending and descending sides and the values given in Table I are the average of the two sets of data except in the cases specified where the descending pattern alone was used (48).

The protein concentrations of the sera were determined by falling drop method standardized by Kjeldahl analyses (48). Hemoglobin concentrations were determined by a photoelectric method using acid hematin. Urine specimens were screened for the presence of protein with $20 \%$ sulfosalicylic acid. Collections were made under toluene at room temperature and stored at $4^{\circ} \mathrm{C}$. The concentration of protein in the urine was determined by the precipitation method of Addis using Tsuchiay's reagent, centrifuging, and comparing the volume of precipitate with a bovine serum albumin control.

\section{OBSERVATIONS}

Seven patients had major abnormalities in the serum protein components. Case numbers refer to consecutive patients found to have multiple myeloma during the period of this study.

Case 1. A. R., C19679. The clinical and hematologic findings which led to the diagnosis of multiple myeloma in this 49 year old woman in October 1947 and her early response to urethane therapy have been reported (2). She has been followed for over 28 months. Her general health remains good, and she works regularly. On three occasions at six to nine month intervals she noted the return of mild symptoms-aching, malaise and mild feverishness-coinciding with increasing proteinuria. These exacerbations of her disease subsided with the administration of more urethane (Figure 1).

The serum proteins were studied electrophoretically on 14 occasions. Before therapy the pattern was conspicuously abnormal (Figure 2, T627).

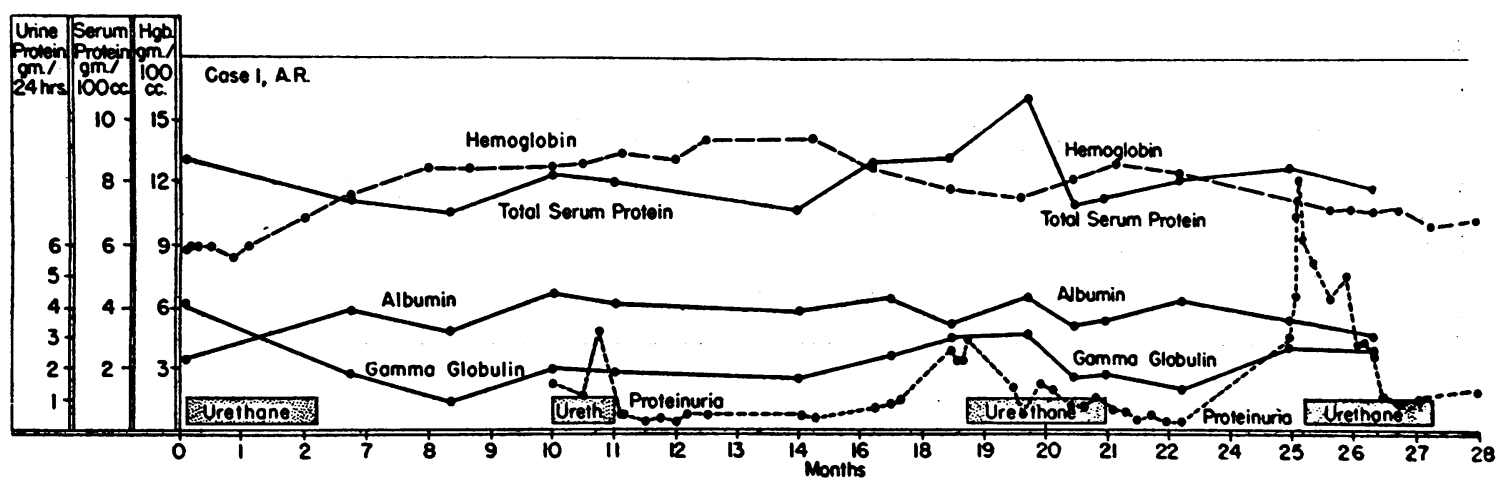

Fig. 1. Graph Showing Changes in Hemoglobin, Total Serum Protein, Albumin, Gamma Globulin and Proteinuria With Courses of Urethane in Case $1, \mathrm{~A}$. $\mathrm{R}$. 


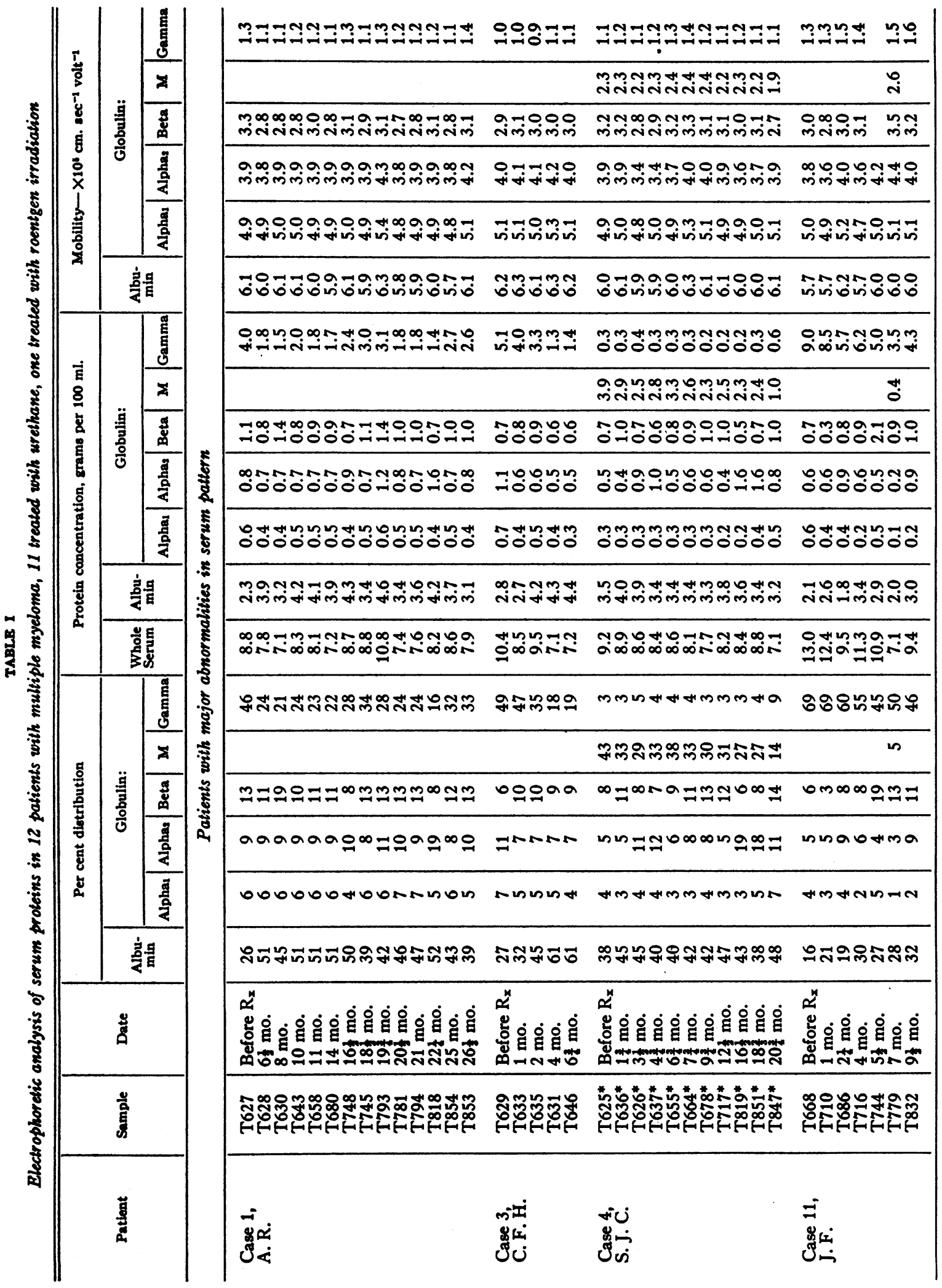




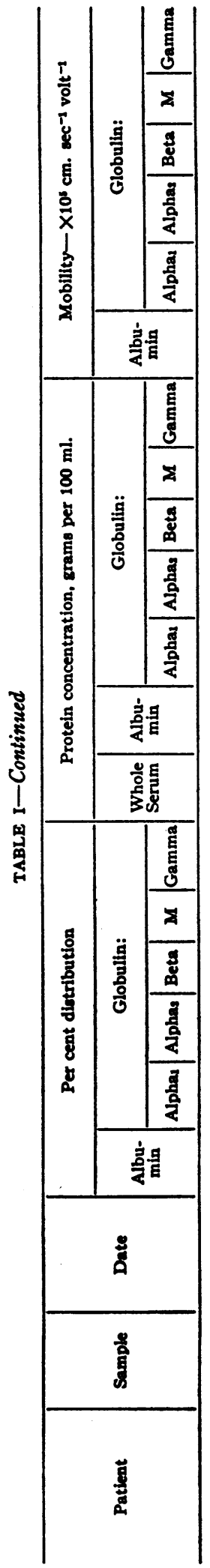

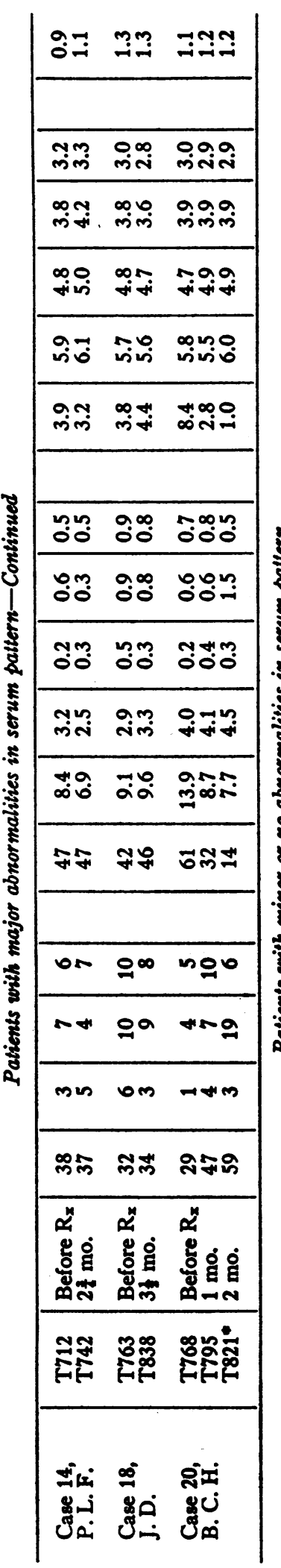

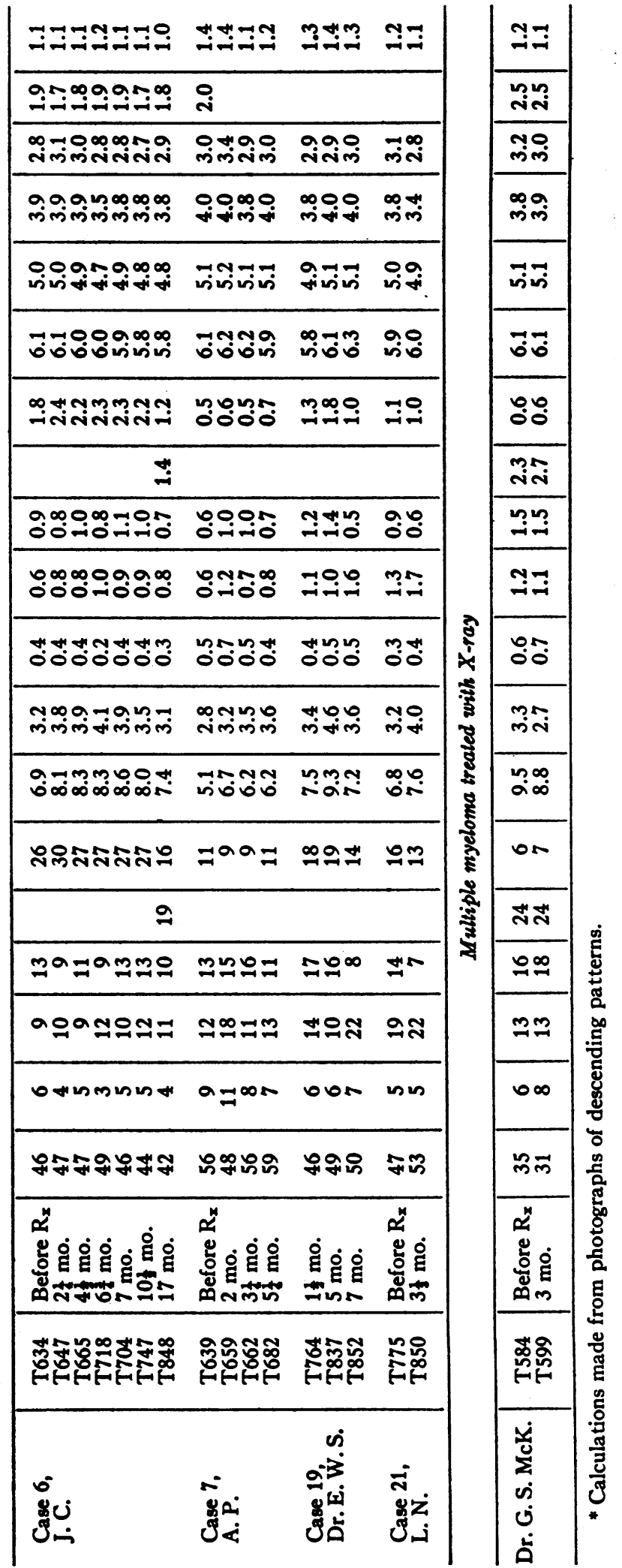




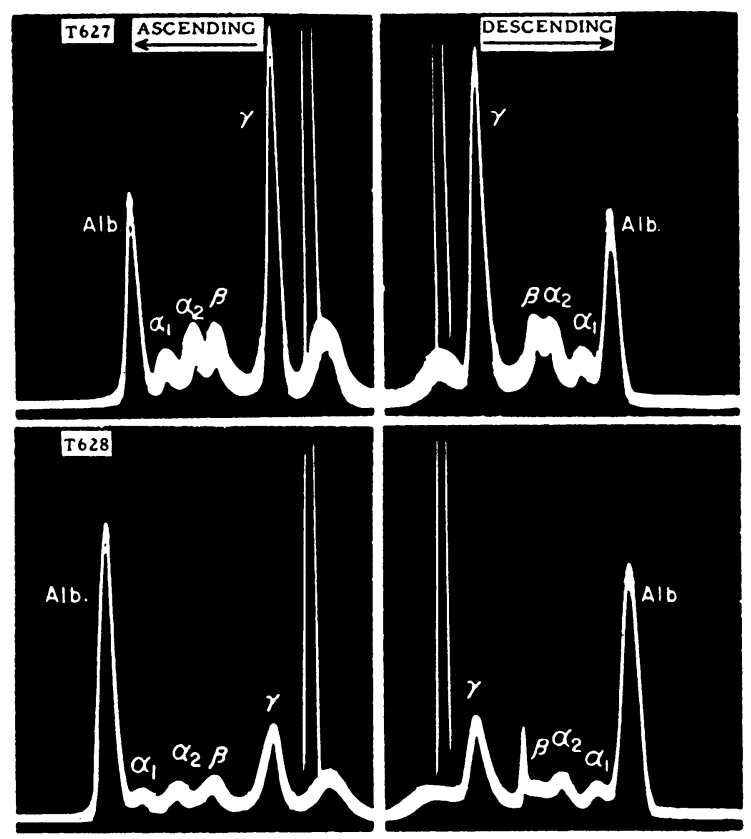

Fig. 2. Pitotograpis of Electrophoretic Serum Patterns, Case 1, A. R., T627 before Therapy, T628, 61/2 Months after Beginning Urethane

A tall, sharp peak was present in the gamma globulin region which measured $46 \%$ of the total refractive area. The albumin was reduced to $26 \%$. A second electrophoretic study six and one half months later, when the percentage of plasma cells in the bone marrow was greatly reduced and evidence of activity of her disease minimal, showed that protein with gamma mobility had fallen to $24 \%$. The albumin had increased to $51 \%$. The pattern was virtually normal except for sharpness in the gamma protein boundary indicative of abnormal homogeneity (Figure 2, T628).

The effect of the four courses of urethane therapy on the hemoglobin, total serum protein, albumin and gamma globulin concentrations and amount of protein excreted in the urine is shown in Figure 1. After the first period of urethane the total serum protein and the gamma globulin decreased, and the hemoglobin and albumin concentrations rose conspicuously. During the weeks preceding the three comparatively mild relapses in her disease, the total serum protein concentration and especially that of the gamma globulin increased and the hemoglobin fell slightly. The most obvious indication of reactivation of her disease on each occasion was an increase in proteinuria.
The abnormal gamma protein component remained homogenous and constant in relation to other serum proteins throughout the period of observation. The electrophoretic mobility of the gamma protein as a whole did not change consistently in any way dependent on the amount of abnormal protein present.

Case 3. C. F. H., B25150. The clinical findings in this 41 year old colored woman with multiple myeloma have been reported $(2,49)$. After three to four weeks of urethane she became free of the pain associated with her extreme skeletal disease and in three to four months was able to be active at home. Abnormal plasma cells disappeared from the bone marrow, and her hemoglobin rose to a normal level. Eight months after her initial therapy she developed a retro-peritoneal pelvic tumor. The blood values remained normal and there was no increase in abnormal plasma cells in the bone marrow. She was operated upon, and a fleshy plasmacytoma was found infiltrating about the iliac vessels and mesacolon. Resection was attempted and she died of hemorrhage two days after operation.

The serum proteins were studied electrophoretically on five occasions (Table I). Before therapy

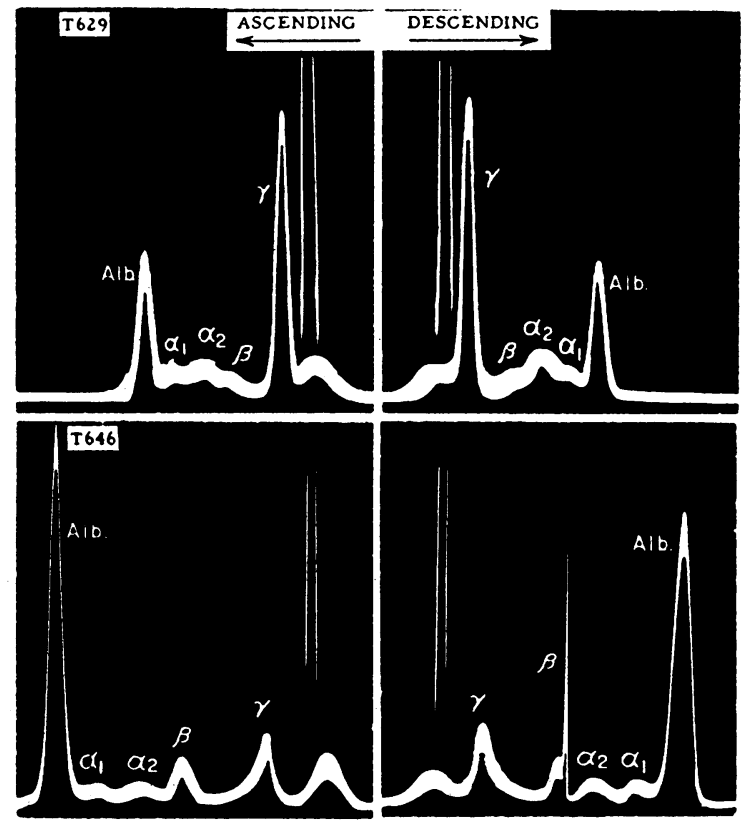

Fig. 3. Photographs of Electrophoretic Serum Patterns, Case 3, C. F. H., T629 before Therapy, T646, 6\% Months after Beginning URethane 


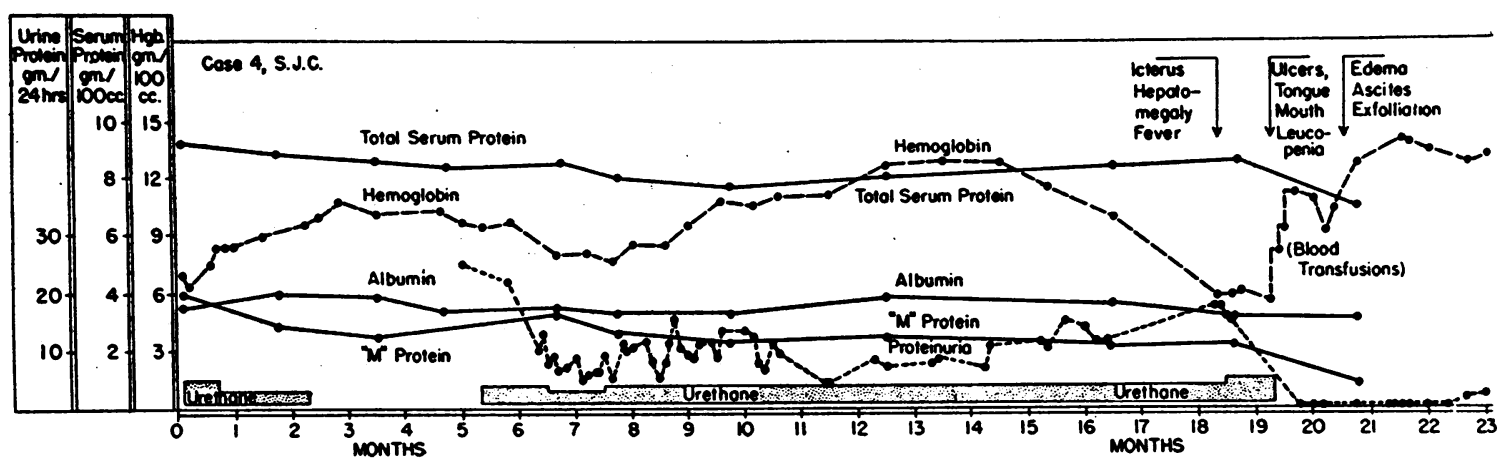

Fig. 4. Graph Showing Changes in Hemoglobin, Total Serum Protein, Albumin, "M" Protein, and Proteinuria With Urethane in Case 4, S. J. C.

the serum protein concentration was 10.4 grams per $100 \mathrm{cc}$. A tall, sharp protein peak comprising $49 \%$ of the total refractive area was present in the gamma globulin (Figure 3, T629). The albumin was reduced to $27 \%$. One month after the beginning of therapy the total serum proteins had dropped to 8.5 grams, largely due to a fall of 1.1 grams in the gamma globulin and 0.8 grams in the alpha globulin. During the second month the gamma globulin concentration continued to fall and the albumin rose sharply. From the fourth month on the electrophoretic pattern of the serum was virtually normal, except for persistent sharpness in the gamma globulin boundary (Figure 3, T646). A serum specimen in the last weeks of her life during the development of the plasmacytoma was unfortunately not preserved.

Case 4. S. J. C., C28643. The clinical and hematologic findings which led to the diagnosis of rapidly progressive multiple myeloma in this 54 year old electrician in February 1948, and his early response to urethane have been reported (2). An incomplete remission followed the first therapy and three months later urethane was resumed (Figure 4). Heavy proteinuria persisted and the hemoglobin rose but slowly. For this reason urethane was given continuously for 14 months, 1275 grams in all. Three months after the beginning of treatment he resumed his usual work, and for the next 12 months his general health was good.

During the 15th month the hemoglobin began to fall and the proteinuria increased (Figure 4). During the next few weeks he became progressively weaker. At $181 / 2$ months his liver and spleen were found to have enlarged and there was tenderness to pressure on the sternum. He was slightly icteric and febrile. The hemoglobin was 5.8 grams per $100 \mathrm{cc}$. His bone marrow was found to contain $80 \%$ abnormal plasma cells. Liver function studies showed the thymol turbidity test to be negative, blood bilirubin $2.8 \mathrm{mgm}$. per 100 cc., and the alkaline phosphatase, which had been normal earlier in his illness, elevated to 9.4-10.6 Bodansky units. There was slight retention of the bromsulfalein dye at 30 minutes $(5 \mathrm{mgm}$. per kg.).

It was thought best, since relapse had occurred in spite of the continuous administration of 3 grams of urethane a day, to increase the daily dose to 4 grams. At the end of another month he was no better. His hemoglobin remained about 6 grams per $100 \mathrm{cc}$. and the number of leucocytes dropped to 1050 per cu. mm. Deep ulcers developed on his tongue and over the hard palate. Urethane was stopped, with the expectation that a fatal exacerbation of his disease would occur. A series of blood transfusions were given. Immediately following the transfusions the red cell count and hemoglobin continued to fall gradually but after two weeks they began to rise and became entirely normal (Figure 4). The total and differential leucocyte count became normal. The proteinuria which had gradually increased during the urethane therapy to average $16-19$ grams per day was discovered to have fallen to $0.25-0.5$ gram per day.

During the month following the cessation of urethane therapy the mouth ulcers healed and he became generally stronger. Five weeks after the urethane was discontinued he abruptly developed edema of the legs, ascites, and generalized cutane- 
ous exfoliation. The elevation in blood bilirubin and alkaline phosphatase persisted. The exfoliation subsided in two to three weeks time, but ascitic fluid continued to form and required repeated paracenteses. The peripheral blood counts remained normal and the proteinuria minimal. Another bone marrow specimen two months after urethane was discontinued showed $30 \%$ abnormal plasma cells with regressive changes similar to those seen after initial therapy. A needle biopsy of the liver showed central and mid-zonal hepatic degeneration and fibrosis (Dr. Leland Stoddard).

Ascites and other evidence of hepatic disease continued. He began to have hematemeses. A few days before his last admission to the hospital on May 6, 1950, severe skeletal pain recurred.
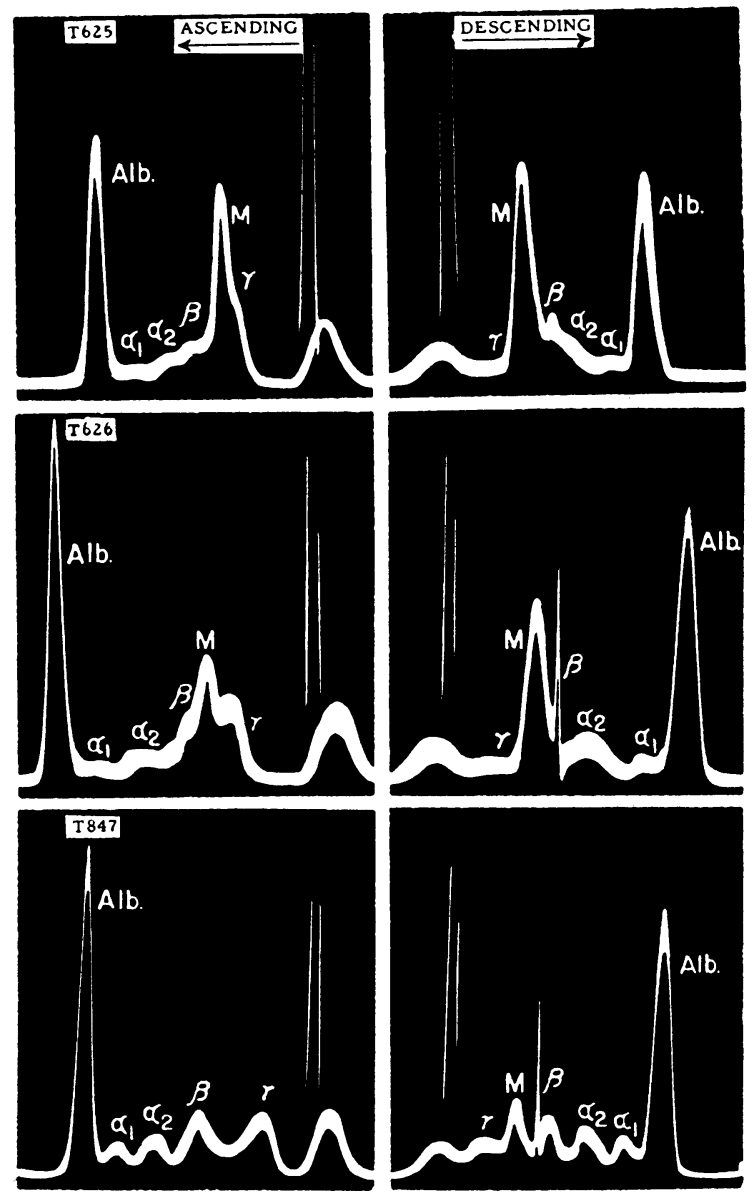

Fig. 5. Photographs of Electrophoretic Serum Patterns, Case 4, S. J. C., T625 before Therapy, T626, $31 / 2$ Months after Beginning Urethane, and T847 at 203/4 Months, 5 Weeks after Suspension of Urethane THERAPY
With a slight fall he suffered an intertrochanteric fracture of the femur where roentgen films showed multiple osteolytic lesions. His urine contained over $1 \%$ protein and his bone marrow was almost completely filled again with abnormal plasma cells. He died 261/2 months after his disease was first discovered.

Eleven electrophoretic analyses of the serum proteins were made. Before therapy the major abnormality was a tall, sharp peak with a mobility intermediate between beta and gamma globulin (Figure 5, T625). In the electrophoretic analyses the abnormal component did not separate satisfactorily from neighboring beta and gamma components on the ascending side of the cell. Mobilities and protein concentrations, accordingly, were calculated from photographs of the descending side. The abnormal " $M$ " component before therapy accounted for $43 \%$ of the total refractive area. The albumin was reduced to $38 \%$. One and three quarter months after the beginning of therapy the "M" protein had fallen to $32 \%$ and the albumin had risen to $45 \%$. This trend was still present at three and one half months (Figure 5, T626), but reversed as he relapsed. With continuous urethane therapy the abnormal protein component again fell to a level of 2.3-2.6 grams per $100 \mathrm{cc}$. Analyses at $161 / 2$ and $18 \%$ months, before urethane therapy was suspended, showed an increase in alpha ${ }_{2}$ globulin and a fall in albumin.

A striking change in the electrophoretic pattern was present six weeks after cessation of urethane therapy (Figure 5, T847). The pattern on the ascending side was abnormal only as to increased height and sharpness of the gamma component. On the descending side the " $M$ " component separated well for the first time from gamma globulin. Its concentration was only 1.0 gram per $100 \mathrm{cc}$.

Case 11. J. F., C47338. This 72 year old lawyer, first admitted to Duke Hospital on November 6,1948 , had been generally healthy until three to four years earlier when susceptibility to pulmonary infections during the cold weather and proteinuria developed. Nine months before admission he stepped down from a curb and was struck with a severe low back pain. Skeletal pain gradually became more extensive and severe until he was extremely uncomfortable even at bed rest.

On admission to the hospital a normochromic, 
normocytic anemia with the hemoglobin reduced to $11.0 \mathrm{grams}$ was found. The urine contained 1.52.2 grams of protein each day that gave the heat coagulation reactions of Bence Jones protein. $\mathrm{X}$-rays of the skeleton showed generalized osteoporosis and osteolytic lesions in the skull, ribs, clavicles, vertebrae, pelvis, upper humeri and femora. The bone marrow contained $41 \%$ abnormal plasma cells. He was given 210 grams of urethane by mouth in a period of eight weeks during which time he became free of pain and able to walk about cautiously. The proteinuria dropped to 0.5 gram per 24 hours. A second bone marrow examination showed the persistence of a large number of plasma cells, but morphologic changes associated with retarded growth were evident. $\mathrm{He}$ developed bronchopneumonia again and was critically ill for several weeks. Urethane was resumed in somewhat irregular fashion five and one half months after the beginning of the initial therapy. Four months later he was able to undertake modest activity about his home. Sixteen months after the beginning of therapy he continued to enjoy improved health.

Before therapy the serum proteins were elevated to 13.0 grams per $100 \mathrm{cc}$. In the electrophoretic pattern an extremely high, sharp protein peak was present in the gamma region, comprising $69 \%$ of the total refractive area (Figure 6, T668). The albumin was reduced to $16 \%$. During the first month of urethane therapy there was a drop in total serum protein and in gamma protein with a rise in albumin. A third study at two and one quarter months, during the bronchopneumonia episode, showed a continued fall in globulin. After five and one half months, following resumption of urethane, there was further progress toward normal although the abnormal gamma component remained conspicuously elevated and the albumin reduced.

Case 14. P. L. F., C8339. The clinical findings which led to the diagnosis of multiple myeloma in this 53 year old merchant's wife, whose presenting trouble was a tumor of the right scapula, have been reported (49). During a period of eight weeks after the diagnosis was made she was able to take 160 grams of urethane. Pain and swelling about the scapula decreased markedly. During the last three weeks of treatment she was persistently nauseated, ate little, and the white blood
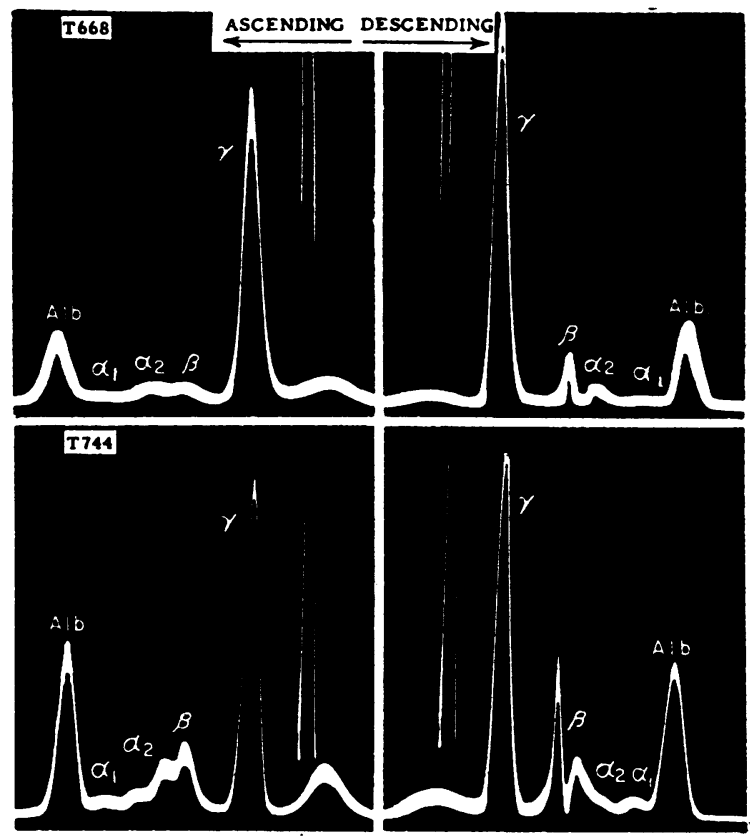

Fig. 6. Photographs of Electrophoretic Serum Patterns, Case 11, J. F., T668 before Therapy, and T744, 51/2 Months after Beginning Urethane Therapy

count hovered at about half of the pre-treatment level. The hemoglobin and red blood count fell slightly during this period but subsequently rose. There was little observable change in the plasma cells in the marrow. After the urethane was stopped she remained weak, complained of nausea, upper abdominal discomfort and noted afternoon fever. After two weeks of these symptoms she developed ascites. Homologous serum jaundice was suspected. On re-investigation the blood bilirubin was $1.1 \mathrm{mgm}$. per $100 \mathrm{cc}$. There was slight retention of the bromsulfalein dye at 45 minutes. A thymol turbidity test was negative. A 2-4 p.m. urine specimen contained 7.3 Ehrlich units of urobilinogen and no bilirubin. There was no protein in the urine. A needle biopsy of the liver showed centrilobular hemorrhage or severe congestion and parenchymal degeneration (Dr. Leland Stoddard). Ascites persisted and required repeated paracenteses until her death seven months after the initial therapy was given. Two weeks before she died she fractured her humerus while turning over in bed.

The serum proteins were elevated to 8.4 grams per $100 \mathrm{cc}$. before therapy (Table I). In the electrophoretic pattern a high, sharp peak accounting 


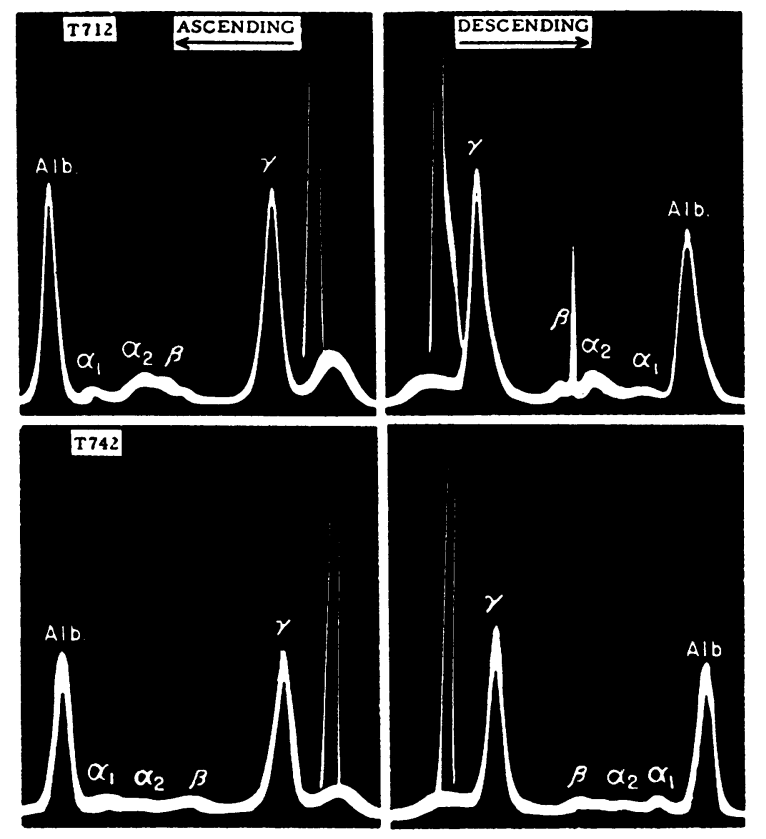

Fig. 7. Photographe of Electrophoretic Serum Patterns, Case 14, P. L. F., T712 before Therapy, and T742, 23/4 Months after Beginning Lrethane Therapy

for $47 \%$ of the total refractive area was present in the gamma protein. The albumin was reduced to $38 \%$. Two and three quarter months after the start of urethane therapy the total serum protein had fallen 1.5 grams, but the electrophoretic pattern showed no essential change (Figure 7, T712 and T742).

Case 18. J. D., C60817. This 58 year old colored farmer was admitted to Duke Hospital on May 10, 1949. His general health had been failing for one year. Low back pain developed one or two months before his admission and became progressively more severe. Roentgen examination showed osteolytic skeletal lesions in the ribs, vertebrae, pelvis, proximal femora and humeri. A normochromic, normocytic anemia was present with the hemoglobin reduced to 11.0 grams per $100 \mathrm{cc}$. Bone marrow aspirated from the sternum showed $30 \%$ abnormal plasma cells. Bence Jones protein amounting to $0.1-0.25$ gram per 24 hours was present in the urine. He was given 245 grams of urethane in a period of 10 weeks and believed that he noted slight symptomatic improvement. The quantity of protein in the urine was minute. A second bone marrow examination showed, however, that plasma cells persisted with little quali- tative or quantitative change. A month after the urethane was discontinued a lumbar vertebra collapsed. Urethane was resumed but he continued to fail and died five months after his first treatment.

The total serum proteins were elevated to 9.1 grams per $100 \mathrm{cc}$. before therapy (Table I). In the electrophoretic pattern a tall, sharp peak in the gamma protein accounted for $42 \%$ of the total refractive area. The albumin was reduced to $32 \%$. A second electrophoretic analysis three and one half months after the beginning of therapy showed a slight rise in total protein, albumin and gamma globulin without significant change in pattern.

Case 20. B. C. H., C63673. This 28 year old law student, referred by Dr. W. G. Morgan of Chapel Hill, was admitted to Duke Hospital on June 20, 1949. After discharge from service he had attended school regularly, but his general health had been under par for two or three years. In January 1949, he developed a febrile illness and typhoid bacilli were cultured from his stool. $\mathrm{He}$ was treated with Chloromycetin and his fever subsided. The persistence of anemia with leukopenia and proteinuria several weeks later led to further study. On admission to the hospital he was acutely and chronically ill. Hemorrhages and exudates were present in both optic fundi. The blood pressure was normal. His pulse was rapid, his heart moderately enlarged and at the apex there was a loud systolic murmur. X-ray examination of the skeleton showed no bony abnormalities. Examination of the blood showed a normochromic, normocytic anemia with the hemoglobin 7.5 grams per $100 \mathrm{cc}$. The leucocyte count was reduced to 2000 . Bone marrow aspirated from the sternum showed $64 \%$ abnormal plasma cells. The urine contained from 0.4-0.9 gram protein per 24 hours that gave qualitative reactions of Bence Jones protein.

Urethane was given cautiously because of the leukopenia to a total dose of 90 grams in nine weeks. During the first few days of urethane therapy his hemoglobin fell to 6.1 grams. He became weak, fainted when out of bed, developed tachycardia and a gallop rhythm. He was given two blood transfusions and parenteral fluids with symptomatic improvement. Regeneration of blood was apparent at the end of three weeks of therapy and during the following six weeks his blood values 
became entirely normal. Protein disappeared from the urine. Abnormal plasma cells underwent regressive changes and disappeared from the bone marrow. His general health became perfectly good. Six months after the initial therapy a small amount of protein reappeared in the urine, and his hemoglobin and red blood cell count began to fall. A second course of urethane was begun.

Before therapy a striking hyperproteinemia was present with the total serum protein being 13.9 grams per $100 \mathrm{cc}$. (Table I). Electrophoretic analysis showed a high, sharp protein peak of gamma mobility comprising $61 \%$ of the total refractive area (Figure 8, T768). The albumin was reduced to $29 \%$. During the first month of urethane the total protein fell 5.2 grams, the net change representing a fall of 5.6 grams of gamma globulin and slight rise in albumin and alpha and beta globulins (Figure 8, T795). During the next month there was a further fall in gamma globulin and rise in albumin. An unexplained alteration in alpha ${ }_{2}$ globulin was observed (Figure 8, T821).

The following four patients had minor or no abnormalities in electrophoretic pattern of the serum.

Case 6. J. C., C27868. This 37 year old farmer developed flaccid paralysis of the lower extremities in April 1948, after having had radicular pain of increasing severity about his mid-trunk for six or seven months. Examination of the spinal fluid showed a block in the thoracic region. Laminectomy at D 8-10 disclosed a partially resectable tumor producing spinal cord compression. The pathologic diagnosis was plasmacytoma. Subsequent X-rays of the skeleton showed an area of osteolytic destruction behind the right orbit and at the anterior end of the left seventh rib. Examination of the peripheral blood showed no abnormalities. Marrow aspirated from the sternum contained $4.5 \%$ abnormal plasma cells. There was no protein in the urine. He was given 210 grams of urethane in a period of two months, largely as a prophylactic measure. His neurologic recovery was good with only the expected residuals resulting from spinal cord compression.

Early in February 1949, he had an acute recurrence of weakness, increased spasticity and incoordination of his legs. There was a very slight fall in the hemoglobin, red cell count and hematocrit, and 2 second bone marrow examination showed $11 \%$ abnormal plasma cells. Examination of the spinal fluid showed no cellular or dynamic abnormalities and no increase in protein. A second course of urethane therapy, 197 grams in six weeks time, was given and his symptoms subsided. On a check-up examination $141 / 2$ months after the first urethane therapy no new developments were discovered except that skull films showed new areas of bony rarefaction. At 17 months he returned complaining of having developed severe pain over a rib after chopping wood. Examination showed local rib tenderness and for the first time definite tenderness to pressure over the sternum. Roentgen films showed further increase in the size of the osteolytic lesions in the skull. The hemoglobin, cell counts and hematocrit remained

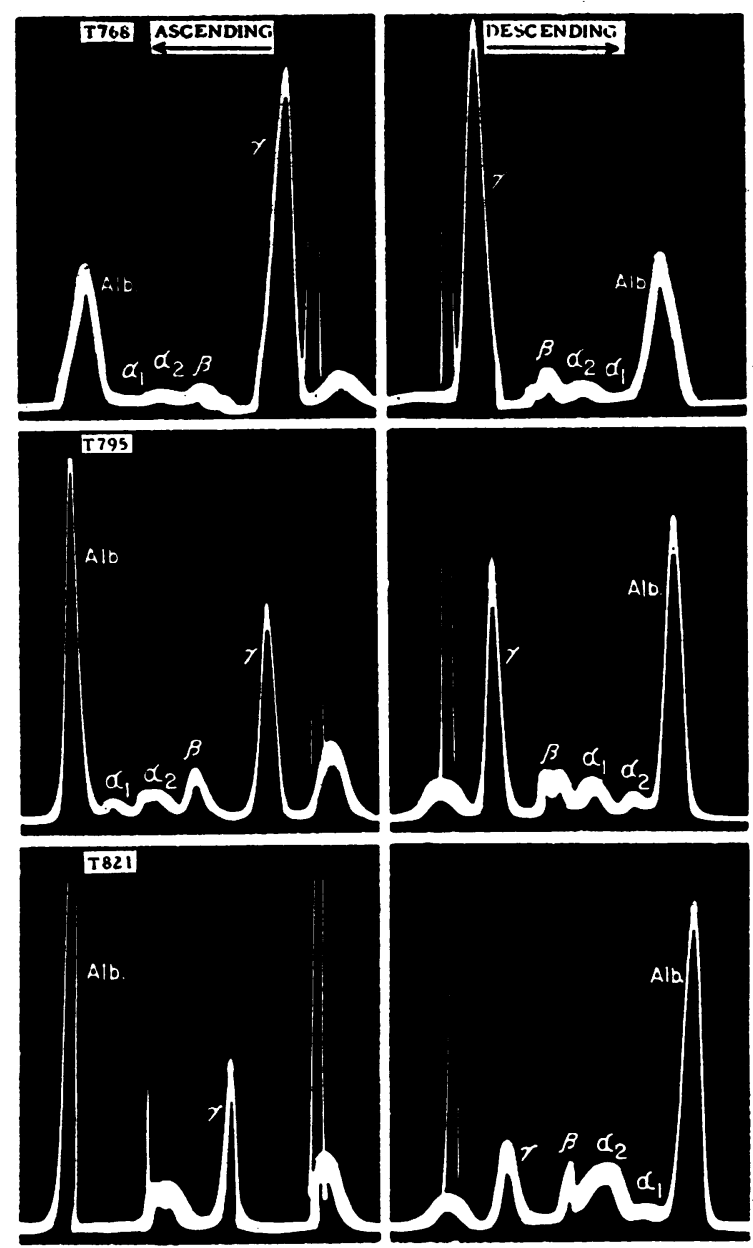

Fig. 8. Photographs of Electrophoretic Serum Patterns, Case 20, B. C. H., T768 before Therapy, T795 after One Month of Urethane, and T821 after Two Months of URethane 

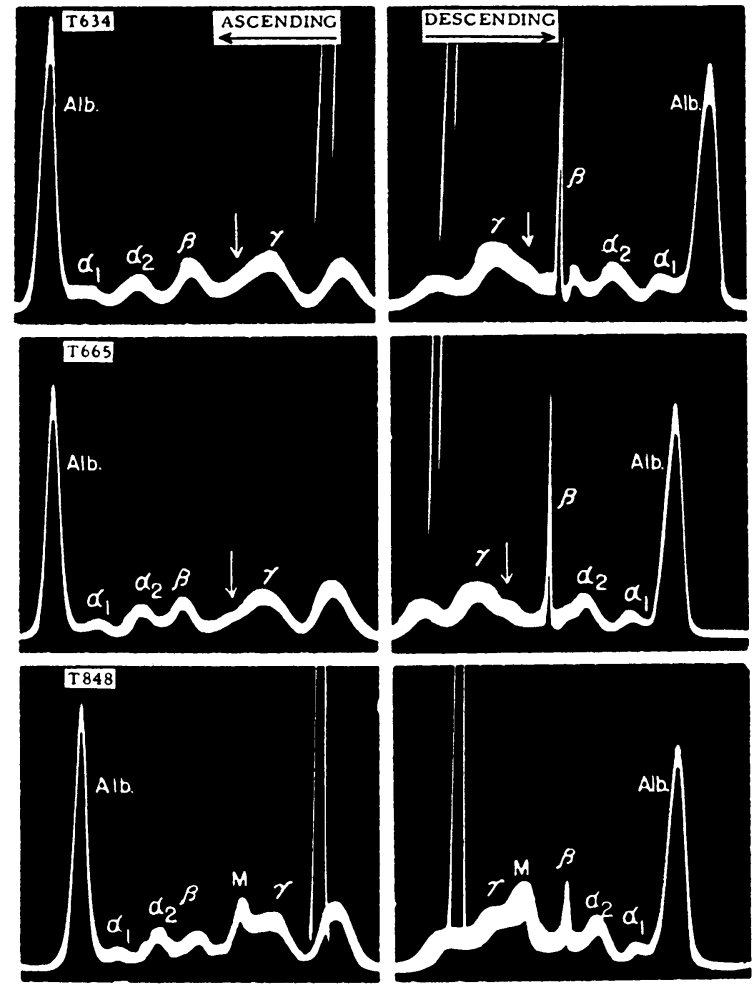

Fig. 9. Photographs of Electrophoretic Serum Patterns, Case 6, J. C., T634 before Urethane TherAPY, T665 after 41/2 Months, T848 at 17 Months with Activation and Spread of Disease

at normal levels but in the blood films there was an occasional plasma cell. Bone marrow aspirated from a tender area of the sternum contained $90 \%$ abnormal plasma cells. Repeated examinations of the urine throughout the course of his illness showed no protein.

The serum proteins were studied by electrophoresis on seven occasions. The first study was made during his convalescence from the laminectomy when the total protein was 6.9 grams per $100 \mathrm{cc}$. Gamma protein was increased to $26 \%$ (Table I). On the fast moving side of this constituent a small abnormal component showed beginning separation (Figure 9, T634). After the first urethane therapy, however, this component became only a little less conspicuous (Figure 9, T665). There was likewise very little change in the serum protein components before and after the second course of urethane. The pattern at 17 months, however, when there was more extensive disease, showed a new development. In the region of the previously uncertain abnormality a new protein peak with mobility intermediate between gamma and beta globulin appeared for the first time (Figure 9, T848).

Case 7. A. P., 59026. This 45 year old sometime farmer had diagnostic studies at Duke Hospital in December 1945, shortly after he had developed an incomplete flaccid paralysis of the lower extremities. X-ray films of the skeleton showed generalized osteolytic bony disease. Heavy proteinuria was present, averaging 13-17 grams per 24 hours. There was no anemia. Twenty-six per cent of the cells in a bone marrow specimen were plasma cells. He was discharged home without specific treatment. He gradually became able to move around again and became freer of pain. $\mathrm{He}$ was given $\mathrm{X}$-ray therapy over the upper thoracic spine. His ribs and humeri fractured repeatedly and he was never able to work.

He returned for re-examination on July 30, 1948. X-rays of the skeleton showed extreme bony disease involving the skull, vertebrae, clavicles, scapulae, ribs, pelvis, upper femora and humeri. Blood examination showed his hemoglobin to be 10.5 grams, RBC 3.4 million, WBC 2950, hematocrit $31 \%$, and average cell volume 91 cubic
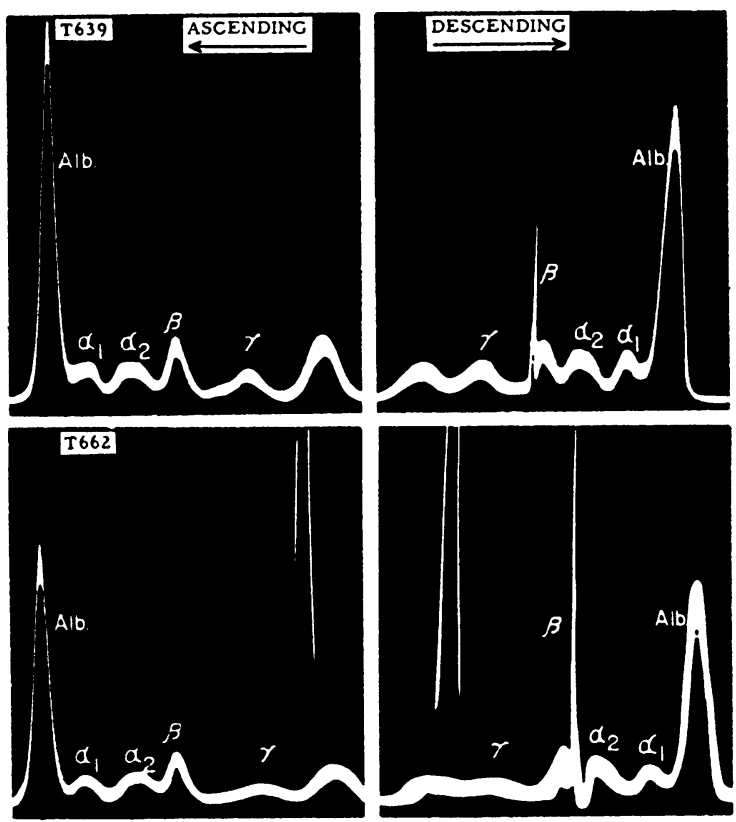

Fig. 10. Photographs of Electrophoretic Serum Patterns, Case 7, A. P., T639 before Urethane, T762, 31/4 Months after Beginning Urethane Therapy 

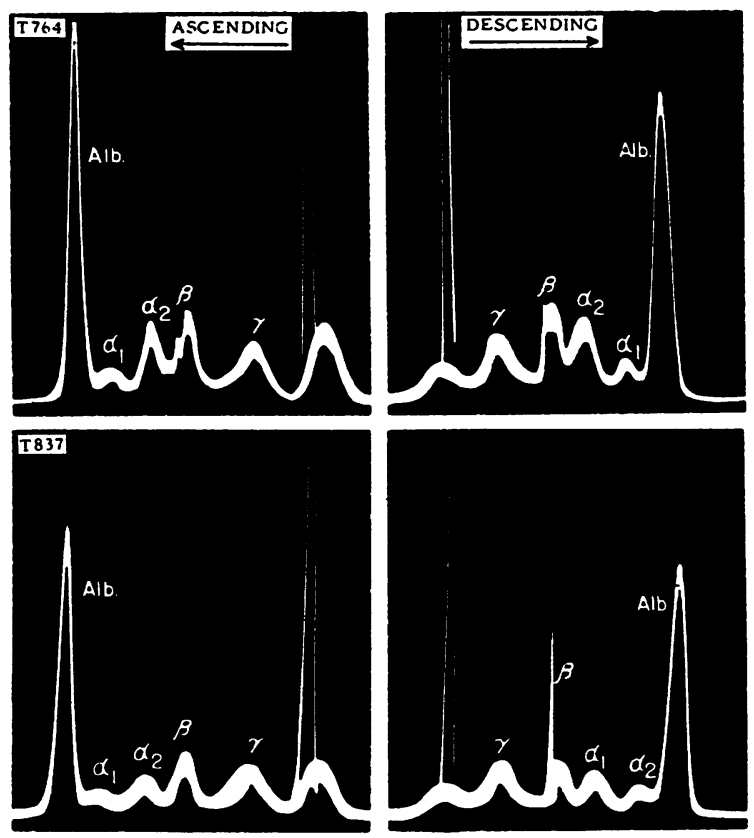

Fig. 11. Photographs of Electrophoretic Serum Patterns, Case 19, Dr. E. W. S., T764 after 13/4 Months of Urethane, T837, Five Months after Beginning THERAPY

micra. Different specimens of bone marrow showed 8-24\% abnormal plasma cells. Bence Jones proteinuria ranged from 17-20 grams per 24 hour period.

He was given 243 grams of urethane during a period of two and one half months. Three months later his blood values were normal, and the proteinuria averaged about 4 grams per 24 hours. Seven months after the beginning of therapy the blood values dropped slightly and proteinuria ranged from 2.4-3.4 grams per day. Another course of urethane was given. He became virtually free of skeletal complaints and was able to return to regular work.

Before therapy the serum proteins were reduced to 5.1 grams per $100 \mathrm{cc}$. (Table I). The electrophoretic pattern showed some sharpness of the gamma boundary (Figure 10, T639). A tiny peak intermediate between the gamma and beta protein was present on the ascending side but subsequently was not observed. Protein obtained from the urine showed on electrophoretic analysis a sharp symmetrical peak moving with gamma mobility and a very small amount of albumin. When the urinary protein was added to the serum, the electrophoretic pattern showed a new peak in the center of the gamma protein.

Subsequent electrophoretic studies at two, three and one quarter and five and one quarter months after the beginning of therapy showed an increase in the serum albumin and some flattening of the gamma boundary.

Case 19. Dr. E. W. S., C61008. The findings which led to the diagnosis of multiple myeloma in this 42 year old physician and his early response to urethane have been reported (49). After the first few weeks of therapy his urine was consistently free of protein. Seven months after the first urethane was given there was a recurrence of pain, heat and swelling in the areas of skeletal disease. A second course of urethane, 200 grams, was given with symptomatic benefit.

The first electrophoretic study of the serum one and one half months after beginning of urethane therapy showed a rather sharp gamma globulin peak with possibly a component separating out from the fast portion that was not evident later (Figure 11, T764). A second study at five months, when there was less evidence of activity in his disease, showed the total serum protein to be 9.3 grams per $100 \mathrm{cc}$. The albumin concentration had increased (Table I). The gamma globulin pattern had shown little change (Figure 11, T837). A third electrophoretic study at a time when the disease was becoming active again showed less albumin, an increased sharpness of the gamma globulin and changes in the alpha 2 and beta globulins difficult to interpret.

Case 21. L. N., A33105. The findings which led to the diagnosis of multiple myeloma in this 46 year old married woman admitted to Duke Hospital on May 31, 1949, with spinal cord compression due to collapse and wedging of the sixth thoracic vertebra, have been abstracted (49). She was given 245 grams of urethane in a period of nine weeks. At three and one third months she was virtually free of symptoms.

The serum proteins before therapy were 6.8 grams per $100 \mathrm{cc}$. (Table I). In the electrophoretic pattern there was a rather high, sharp alpha 2 peak which merged with the beta globulin. A second electrophoretic study three and one half months later showed a rise in albumin, a slight rise in alpha $a_{2}$ and a slight fall in beta globulin. Abnormalities definitely related to myeloma were not observed. 
The lack of effect of X-ray therapy on the electrophoretic pattern in one patient with multiple myeloma is illustrated by the following case history.

Dr. G. S. McK., A42283. This 66 year old physician developed pain about his ribs on the lower right side and about his left hip in January 1946. A destructive tumor involving the left scapula was discovered. Biopsy led to the diagnosis of plasmacytoma. Between January 26, 1946 and February 15, 1946, he was given roentgen therapy over the left scapula and upper thorax. A large destructive area appeared in the left ilium during the next six weeks. Further irradiation was given between April 8, 1946 and April 15, 1946 over the pelvis. During the period of roentgen irradiation the hemoglobin fell from 12.0 grams to 8.4 grams, red blood count from 3.74 to 2.50 million, and the white blood count from 7250 to 4300 .

Before therapy the serum proteins were elevated to 9.5 grams per $100 \mathrm{cc}$. (Table I). Electrophoretic analysis showed a large abnormal " $\mathrm{M}$ " component comprising $24 \%$ of the total refractive area moving between the gamma and beta globulins. The albumin was reduced to $35 \%$. Three months later there was fall of 0.6 gram per $100 \mathrm{cc}$. albumin and a rise in the abnormal " $\mathrm{M}$ " component of 0.4 gram.

His condition continued to deteriorate and he was given $\mathrm{P} 32$ and stilbamidine therapy. $\mathrm{He}$ died ten months after the first appearance of the disease.

\section{DISCUSSION}

Since urethane was introduced as a therapeutic agent in the treatment of leukemia in 1946 by Paterson, Haddow, Ap Thomas, and Watkinson (50), it has become evident that the cells most sensitive to its growth suppressive action are the abnormal granulocytes of myelocytic leukemia and the proliferating plasma cells in multiple myeloma (2, 51-53). The abnormal leucocytes of lymphocytic leukemia and some tumor cells are less regularly affected. Normal lymphocytes, normal granulocytes, erythropoietic elements (54 56) and the centrilobular hepatic cells (57) are affected to the extent that conservative use of the chemical and sharp individualization in dosage is necessary to avoid harmful complications. Selective suppression of the growth of abnormal cells is obtained slowly and may require three weeks to three months to be realized.

In patients with multiple myeloma the concentration of abnormal protein in the serum or of Bence Jones protein in the urine has not been significantly reduced by roentgen therapy, radioactive phosphorus, or stilbamidine $(17,35)$. The changes that follow the use of urethane confirm the therapeutic effect of this chemical and provide some new facts regarding the basic abnormalities in the disease. Seven of the 11 patients studied had hyperproteinemia and a large increment of abnormal protein in the serum. The electrophoretic mobility of the abnormal component was that of gamma globulin in six and intermediate between gamma and beta protein in one. The amount of this protein in the serum was conspicuously reduced in the five patients in whom the growth of plasma cells was suppressed by urethane. There was generally little change in the serum protein constituents until after the first month of therapy and then only after there was evidence that the growth of plasma cells had been suppressed. As the abnormal components disappeared from the serum the initially low levels of serum albumin rose to normal. Completely normal electrophoretic patterns were not restored since some abnormal protein homogeneity remained at the site of the original increment even during the maximum remissions of the disease. In two patients with major serum protein abnormalities, plasma cell proliferation was not appreciably influenced by the urethane given and there was no change in the electrophoretic pattern. In one of these therapeutic failures severe centrilobular hepatic damage was apparently produced.

The quantity of protein in the urine of patients with hyperproteinemia varied from a few milligrams a day to over 20 grams. A quantitative relationship between Bence Jones proteinuria and the amount of abnormal protein in the serum in different patients, or between proteinuria and the degree of impairment of renal function was not apparent $(19,58,59)$. The proteinuria invariably became less as the concentration of abnormal protein in the serum, whether of gamma or other mobility, was reduced.

Minor or no abnormalities were detected in the serum of four patients by electrophoretic analysis. The disease was of limited anatomic extent in 
three. A distinctly abnormal pattern developed in one of them as the myeloma became more generalized. A fourth patient with extreme skeletal disease excreted large amounts of Bence Jones protein of gamma mobility in the urine, had hypoproteinemia and a virtually normal electrophoretic pattern. Following urethane therapy the proteinuria became much less. The concentration of protein in the serum rose to normal, and there was a slight reduction in the gamma protein.

Adams, Alling and Lawrence (17) reported finding abnormal electrophoretic patterns in 29 consecutive cases of diffuse myeloma and stressed particularly the minor serum abnormalities disclosed by using less dilute serum for electrophoresis.

In general it appeared in our patients that the greater the amount of myeloma tissue in the body and the greater its proliferative activity, as judged by the rapidity of the progression of the disease, fever, weight loss, tendency to relapse, etc., the greater was the amount of abnormal protein present in the serum or excreted in the urine. As the growth of plasma cells was retarded or arrested by the administration of urethane, the abnormal serum and urinary proteins decreased proportionately. Our observations are consistent with the view that the proliferating plasma cells in myeloma produce the abnormal proteins circulating in the blood or excreted in the urine. The extent to which the large serum increments represent Bence Jones proteinemia or perhaps complexes of higher molecular weight, which in the process of disintegration give rise to moieties filterable through the glomeruli, remains to be studied.

In our patients the disturbance in protein metabolism appeared to involve the production of a single type of electrophoretically homogenous protein, of gamma mobility or intermediate between gamma and beta. As the abnormal protein increased in the serum the concentration of albumin fell. Changes in the alpha globulins appeared to be correlated with general tissue reactions and perhaps with hepatic cellular degeneration. The qualitative features of the electrophoretic components remained constant in each individual patient throughout the period of observation. A relation between the morphology of the plasma cells, which varies considerably in different patients, and the type of protein abnormality or of the sus- ceptibility of the cells to growth suppression by urethane was not apparent.

The early investigations regarding the biochemical effects of urethane in producing narcosis or growth suppression were reviewed by Haddow and Sexton (60). Warburg found that phenylurethane added to sea water containing eggs of the sea urchin Strongylocentrotus lividus suppressed nuclear and cell division while reducing oxygen consumption only very slightly. Fisher and Stern (61) studied the inhibition of respiration in yeast cells by urethane and presented data to show that more than one respiratory system was involved. In reference to the possible inhibition of dehydrogenases, Haddow and Sexton pointed out that concentrations required to induce narcosis, and often to suppress growth, or likely to occur in vivo, are often far smaller than those required to inhibit enzyme reactions. It was suggested to them that urethane might compete with some natural amine involved in the biosynthesis of nucleotides.

Skipper and his collaborators $(62-64)$ have made an extensive study of the carbamates as related to the chemotherapy of leukemia. They found that nearly any alteration in the ethyl urethane molecule reduced or destroyed its leukopenic and antileukemia activity in mice. Urethane was decomposed within the body largely within 24 hours. Tracer studies using carbonyl- and ethoxylabeled urethane indicated that the decomposition involved a hydrolytic process producing carbon dioxide, ethyl alcohol, and ammonia. A small fraction of carbonyl-labeled urethane was found in all tissues 24 and 48 hours after intraperitoneal injection with little evidence of anatomic localization. Mice with neoplasms failed to catabolize urethane as rapidly as did normal mice.

Our observations in Case 4., S. J. C., may give a clue as to the mechanism by which urethane is effective in multiple myeloma. Early in the course of this patient's therapy plasma cell proliferation was suppressed to the extent that worthwhile clinical improvement and prolongation of life resulted. After 10 months of continuous urethane administration a gradual relapse in the disease occurred, along with apparently toxic manifestations relating at least to the liver and oral mucous membranes. An extraordinary change in plasma cell proliferation was observed after the urethane was 
discontinued. Their number in the bone marrow decreased, morphologic features indicating retarded growth appeared, sternal tenderness disappeared, Bence Jones proteinuria decreased 50-70 fold, and the abnormal protein component in the serum was greatly reduced. The hemoglobin, red and white cell values were again maintained at normal levels in the circulating blood. Evidence of hepatic disease had developed earlier, became more severe after urethane was stopped, and persisted for the remainder of his life. Six months after urethane was withdrawn there was an exacerbation of plasma cell growth. A similar type of centrilobular hepatic degeneration with ascites was produced in another patient without altering observably the course of the myeloma.

These observations are interpreted to indicate that the growth of plasma cells was inhibited anew by the withdrawal of urethane, in fact to a greater extent than on its initial administration, and that during the prolonged use of the chemical the abnormally proliferating cells had become dependent on it in some way.

The existence of metabolic competition between structurally analagous compounds has been demonstrated by the growth inhibiting properties of unnatural metabolites in bacteria and mammalian cells (65-67). Bacteria may become dependent on such compounds as streptomycin that initially suppress growth (68).

While many agents might affect plasma cell growth selectively by one mechanism or another, the acquisition of dependence on such a chemical as ethyl carbamate suggests that the small amount ordinarily fixed in tissue proteins is incorporated as a metabolite. It may be possible to demonstrate an increased amount fixed in tissues after prolonged administration. It may be postulated that urethane suppresses plasma cell proliferation by competing with a metabolite, such as an amino acid especially necessary in their growth, and that in the course of time the processes of protein synthesis become adapted to render it essential. Under the same conditions the production of hemoglobin, erythrocytes, and leucocytes are apparently not affected. Since hepatic damage was present before urethane therapy was suspended in Case 4, the later events can not be interpreted as urethane dependence.
An increase in mitosis (60), in leucocyte count $(55,56)$, and in the excretion of Bence Jones protein in multiple myeloma has been observed not infrequently early in the course of urethane therapy. Accelerated growth has been observed in the presence of subinhibitory levels of competitive metabolites in other instances (67).

\section{CONCLUSIONS}

As plasma cell growth is inhibited by urethane in multiple myeloma, abnormal serum protein components, even those generally found not to represent Bence Jones proteinemia, are reduced or may virtually disappear. This change parallels the reduction or disappearance of Bence Jones proteinuria. During prolonged continuous administration of urethane myeloma cells may become dependent on the chemical.

\section{BIBLIOGRAPHY}

1. Bayrd, E. D., and Heck, F. J., Multiple myeloma; 2 review of 83 proved cases. J.A.M.A., 1947, 133, 147.

2. Loge, J. P., and Rundles, R. W., Urethane (ethyl carbamate) therapy in multiple myeloma. Blood, 1949, 4, 201.

3. Jones, $\mathrm{H}$. Bence, On a new substance occurring in the urine of a patient with mollities ossium. Philos. Tr. R. Soc. London, 1848, 138, 55.

4. Boggs, T. R., and Guthrie, C. G., The Bence-Jones proteinuria in conditions other than myelomatosis; an instance associated with metastatic carcinoma. Bull. Johns Hopkins Hosp., 1912, 23, 353.

5. Brunsting, L. A., and MacDonald, I. D., Primary systematized amyloidosis with macroglossia: a syndrome related to Bence Jones proteinuria and myeloma. Proc. Staff Meet. Mayo Clin., 1947, 22, 67; J. Invest. Dermatol., 1947, 8, 145.

6. Geschickter, C. F., and Copeland, M. M., Multiple myeloma. Arch. Surg., 1928, 16, 807.

7. Hopkins, F. G., and Savory, H., A study of BenceJones protein and of the metabolism in three cases of Bence-Jones proteinuria. J. Physiol., 1911, 42, 189.

8. Jacobson, B. M., and Milner, L. R., The detection of urinary Bence-Jones protein. Am. J. Clin. Path., 1944, 14, 138.

9. Magnus-Levy, A., ther krystallisiertes und amorphes Bence Jones-Eiweiss; Multiple myelom. Ztschr. f. physiol. Chem., 1936, 243, 173.

10. Miller, S. R., and Baetjer, W. A., Bence Jones proteinuria. Some observations on its occurrence, with particular reference to nephritis and hypertension. J.A.M.A., 1918, 70, 137. 
11. Packalen, T., A case of myeloma with spontaneously crystallizing protein in blood serum and urine. Acta med. Scandinav., 1939, 100, 1.

12. Hektoen, L., and Welker, W. H., Immunological differences of crystalline Bence-Jones proteins. Biochem. J., 1940, 34, 487.

13. Ellinger, A., Das Vorkommen des Bence-Jones'schen Körpers im Harn bei Tumoren des Knochenmarks und seine diagnostische Bedeutung. Deutsch. Arch. f. klin. Med., 1899, 62, 255.

14. Jacobson, V. C., A case of multiple myelomata with chronic nephritis showing Bence-Jones protein in urine and blood serum. J. Urol., 1917, 1, 167.

15. Perlzweig, W. A., Delrue, G., and Geschickter, C., Hyperproteinemia associated with multiple myeloma; report of unusual case. J.A.M.A., 1928, 90, 755 .

16. Feller, A. E., and Fowler, W. M., Hyperproteinemia in multiple myeloma. J. Lab. \& Clin. Med., 1938, 23, 369 .

17. Adams, W. S., Alling, E. L., and Lawrence, J. S., Multiple myeloma. Its clinical and laboratory diagnosis with emphasis on electrophoretic abnormalities. Am. J. Med., 1949, 6, 141.

18. Bing, J., Further investigations of hyperglobulinemia. Acta med. Scandinav., 1940, 103, $547 ; 565$.

19. Blackman, S. S., Jr., Barker, W. H., Buell, M. V., and Davis, B. D., On the pathogenesis of renal failure associated with multiple myeloma. Electrophoretic and chemical analysis of protein in urine and blood serum. J. Clin. Invest., 1944, 23, 163.

20. von Bonsdorff, B., Groth, H., and Packalen, T., On the presence of a high-molecular crystallizable protein in blood serum in myeloma. Folia Haematol., 1938, 59, 184.

21. Gutman, A. B., Moore, D. H., Gutman, E. B., McClellan, V., and Kabat, E. A., Fractionation of serum proteins in hyperproteinemia, with special reference to multiple myeloma. J: Clin. Invest., 1941, 20, 765.

22. Holmberg, C. G., and Grönwall, A., Ein neues krystallinisches Serumglobulin. Ztschr. f. physiol. Chem., 1942, 273, 199.

23. Jersild, M., and Pedersen, K. O., An anticomplementary serum from a patient with myeloma, investigated by means of the Svedberg ultracentrifuge. Acta path. et microbiol. Scandinav., 1938, 15, 426.

24. Kekwick, R. A., The serum proteins in multiple myelomatosis. Biochem. J., 1940, 34, 1248

25. Kydd, D. M., Bence Jones protein in serum, J. Biol. Chem., 1934, 107, 747.

26. Malmros, H., and Blix, G., Plasma proteins in cases with high sedimentation rates. Acta med. Scandinav., 1946, Supp. 170, 280.

27. Moore, D. H., Kabat, E. A., and Gutman, A. B., Bence-Jones proteinemia in multiple myeloma. J. Clin. Invest., 1943, 22, 67.
28. Shapiro, S., Ross, V., and Moore, D. H., A viscous protein obtained in large amounts from the serum of a patient with multiple myeloma. J. Clin. Invest., 1943, 22, 137.

29. Svedberg, T., and Pedersen, K. O., The Ultracentrifuge. Clarendon Press, Oxford, 1940.

30. Gutman, A. B., The plasma proteins in disease, in: Advances in Protein Chemistry, edited by Anson, M. L., and Edsall, J. T. Academic Press, New York, 1948, Vol. IV.

31. Bayne-Jones, S., and Wilson, D. W., Immunological reactions of Bence-Jones proteins. Bull. Johns Hopkins Hosp., 1922, 33, 37; 119.

32. Agren, G., A note on the amino acid content of Bence-Jones protein. Acta chem. Scandinav., 1949, $3,301$.

33. Dent, C. E., and Rose, G. A., The Bence-Jones protein of multiple myelomatosis: its methionine content and its possible significance in relation to the aetiology of the disease. Biochem. J., 1949, 44, 610 .

34. Devine, J., An analysis of Bence-Jones protein. Biochem. J., 1941, 35, 433.

35. Brown, R. K., Read, J. T., Wiseman, B. K., and France, W. G., Electrophoretic analysis of serum proteins of blood dyscrasias. J. Lab. \& Clin. Mea., 1948, 33, 1523.

36. Wuhrmann, F., Wunderly, C., and Wiedemann, E., Ueber das Alpha-Globulin-Plasmocytom. Schweiz. med. Wchnschr., 1948, 78, 180.

37. Barr, D. P., Reader, G. G., and Wheeler, C. H., Cryoglobulinemia. I. Report of two cases with discussion of clinical manifestations, incidence and significance. Ann. Int. Med., 1950, 32, 6.

38. Hansen, P. F., and Faber, M., Raynaud's syndrome originating from reversible precipitation of protein. Acta med. Scandinav., 1947, 129, 81.

39. Hill, R. M., Dunlop, S. G., and Mulligan, R. M., A cryoglobulin present in high concentration in the the plasma of a case of multiple myeloma. J. Lab. \& Clin. Med., 1949, 34, 1057.

40. Hill, R. M., Mulligan, R. M., and Dunlop, S. G., Plasma cell myeloma associated with high concentration of plasma lipoprotein. Am. J. Path., 1948, 24, 688 .

41. Lerner, A. B., and Greenberg, G. R., A homomolecular serum protein with anomalous solubilities. J. Biol. Chem., 1946, 162, 429.

42. Lerner, A. B., and Watson, C. J., Studies of cryoglobulins. I. Unusual purpura associated with the presence of a high concentration of cryoglobulin (cold precipitable serum globulin). Am. J. M. Sc:, 1947, 214, 410.

43. Lerner, A. B., Barnum, C. P., and Watson, C. J., Studies of cryoglobulins. II. The spontaneous precipitation of protein from serum at $5^{\circ} \mathrm{C}$ in various disease states. Am. J. M. Sc., 1947, 214, 416.

44. Schwartz, T. B., and Jager, B. V., Cryoglobulinemia and Raynaud's syndrome in a case of chronic lymphocytic leukemia. Cancer, 1949, 2, 319. 
45. Wintrobe. M. M., and Buell, M. V., Hyperproteinemia associated with multiple myeloma, with report of case in which extraordinary hyperproteinemia was associated with thrombosis of retinal veins and symptoms suggesting Raynaud's disease. Bull. Johns Hopkins Hosp., 1933, 52, 156.

46. Martin, N. H., A study of the plasma and tissue globulins in myelomatosis. J. Clin. Invest., 1947, 26, 1189.

47. Dillon, E. S., Dillon, M. L., and Rundles, R. W., Changes in electrophoretic patterns of sera in patients with multiple myeloma treated with urethane. Am. J. Med., 1949, 7, 242.

48. Dillon, M. L., Cooper, G. R., and Menkin, V., Electrophoretic studies on the leukocytosis-promoting factor of exudates. Proc. Soc. Exper. Biol. \& Med., $1947,65,187$.

49. Rundles, R. W., and Reeves, R. J., Multiple myeloma. II. Variability of roentgen appearance and effect of urethane therapy on skeletal disease. Am. J. Roentgenol. (in press).

50. Paterson, E., Haddow, A., Ap Thomas, I., and Watkinson, J. M., Leukemia treated with urethane compared with deep x-ray therapy. Lancet, 1946, 1 . 677.

51. Bedinger, P. L., Further studies on the effect of urethane in leukemia. J. Lab. \& Clin. Med., 1948, 33. 1647.

52. Berman, L., and Axelrod, A. R., Effect of urethane on malignant diseases. Clinical, hematologic and histologic observations on patients with carcinoma, leukemia and related diseases. Am. J. Clin. Path., 1948, 18, 104.

53. Harrington, W. J., and Moloney, W. C., The treatment of multiple myeloma with urethane. Cancer. 1950, 3, 253.

54. Moeschlin, S., Zum Wirkungsmechanismus des Urethans bei Leukámien. Helvet. med. acta, 1947, 14. 279.

55. Moeschlin, S., and Meili, J., Einfluss des Urethans auf das normale Blutbild beim Menschen. Schweiz. med. Wchnschr., 1947, 77, 1351.

56. Moeschlin, S., and Naef, A., Einfluss des Urethans auf das Blutbild der Laboratoriumstiere. Schweiz. med. Wchnschr., 1948, 78, 458.
57. Doljanski, L., and Rosin, A., Studies on the early changes in the livers of rats treated with various: toxic agents, with especial reference to the vascular lesions. I. The histology of the rat's liver in urethane poisoning. Am. J. Path., 1944, 20, 945.

58. Armstrong, J. B., A study of renal function in patients with multiple myeloma. Am. J. M. Sc. 1950, 219. 488.

59. Bell, E. T., Renal lesions associated with multiple myeloma. Am. J. Path., 1933, 9, 393.

60. Haddow, A., and Sexton, W. A., Influence of carbamic esters (urethanes) on experimental animal tumours. Nature, 1946, 157, 500.

61. Fisher, K. C., and Stern, J. R., The separation of an "activity" metabolism from the total respiration of yeast by the effects of ethyl carbamate. J. Cell. Comp. Physiol., 1942, 19, 109.

62. Bryan, C. E., Skipper, H. E., and White, L., Jr., Carbamates in the chemotherapy of leukemia. IV. The distribution of radioactivity in tissues of mice following injection of carbonyl-labeled urethan. J. Biol. Chem., 1949, 177, 941.

63. Skipper, H. E., and Bryan, C. E., Carbamates in the chemotherapy of leukemia. III. The relationship) between chemical structure and anti-leukemia action of a series of urethan derivatives. J. Nat. Cancer Inst., 1949, 9, 391.

64. Skipper, H. E., Bryan, C. E., Riser, W. H., Jr., Welty, M., and Stelzenmuller, A., Carbamates in the chemotherapy of leukemia. II. The relationship) between chemical structure, leukopenic action, and acute toxicity of a group of urethan derivatives. J. Nat. Cancer Inst., 1948, 9, 77.

65. Fildes, P., A rational approach to research in chemotherapy. Iancet, 1940, 1, 955.

66. Woods, D. D., The relation of $p$-aminobenzoic acid to the mechanism of the action of sulphanilamide. Brit. J. Exper. Path., 1940, 21, 74.

67. Wooley, D. W., Recent advances in the study of biological competition between structurally related compounds. Physiol. Rev., 1947, 27, 308.

68. Paine, T. F., and Finland, M., Streptomycin-sensitive, -dependent, and -resistant bacteria. Science, 1948. 107. 143 . 